\title{
First Aeropalynological Survey on the Atmosphere of Sinop,
}

\section{Turkey}

\author{
Talip ÇETER $^{1} \mathbb{E}$, Hülya ÖZLER ${ }^{2 *} \mathbb{D}$, Nur Münevver PINAR $^{3} \mathbb{E}$ \\ ${ }^{1}$ Kastamonu University, Department of Biology, Kastamonu, TURKEY \\ ${ }^{2}$ Sinop University, Department of Biology, Sinop, TURKEY \\ ${ }^{3}$ Ankara University, Department of Biology, Ankara, TURKEY \\ *Corresponding Author: hulyaozler06@gmail.com
}

Received Date: 15.09 .2020

Accepted Date: 06.12 .2020

\begin{abstract}
Aim of study: With this first aeropalynological study in the atmosphere of Sinop, it was aimed to detect seasonal variation of pollen and its relationship with meteorological parameters.

Area of study: This survey was conducted in the atmosphere of the Korucuk district of Sinop.

Material and methods: This study was carried out using Hirst-Burkard 7-day volumetric trap between July 2010 and June 2012.

Main results: During a period of two years, pollen of 61 taxa that included 37 taxa of trees, 23 taxa of other weeds and Poaceae were recorded with the sum of 93,414 pollen grain. Pollen of trees $(69.5 \%)$ predominantly contributed to the pollen sum followed by Poaceae (17.1\%) and other weeds (13.4\%).

Highlights: Alnus (2.6\%), Amaranthaceae (3.4\%), Betula (1.3\%), Carpinus (2.6\%), Compositae (6.2\%), Corylus (23.1\%), Cupressaceae (13.7\%), Fraxinus (1.7\%), Pinaceae (16.1\%), Plantago (1.1\%), Poaceae $(17 \%)$ and Quercus $(2.2 \%)$ were determined as the dominant taxa in the atmosphere. Among the meteorological parameters, temperature and wind speed generally had a positive effect on pollen concentration, while rainfall had a negative effect on it. A pollen calendar was prepared as a result of the pollen grain detected in the atmosphere of Sinop.
\end{abstract}

Keywords: Sinop, Airborne Pollen, Volumetric, Pollen Calendar, Turkey

\section{Sinop (Türkiye) Atmosferine Yönelik İlk Aeropalinolojik}

\section{Araştırma}

Öz

Çalışmanın amacı: Sinop atmosferinde yapılan bu ilk çalışma ile polenlerin mevsimsel değişiminin meteorolojik parametrelerle ilişkisinin tespiti amaçlanmıştır.

Çalışma alanı: Bu çalışma Sinop ili, Korucuk mahallesi atmosferinde yapıllmıştır.

Materyal ve Yöntem: Çalışma, Hirst tipi Burkard tuzağı kullanılarak Temmuz 2010 - Haziran 2012 tarihleri arasında gerçekleştirilmiştir.

Temel sonuçlar: Yapılan 2 yıllık analiz sonuçlarına göre, 37 ağaç ve ağaçsı (\%69.5), 23 otsu (\%13.4) ve Poaceae (\%17.1) olmak üzere 61 taksona ait toplam 93,414 polen tespit edilmiştir. Araştırma periyodunda atmosferde tespit edilen polenlerden; ağaç ve ağaçsı polenler ilk sırayı alırken, Poaceae 2. sırada, otsular 3. sırada yer almıştır.

Araştırma vurgularl: Atmosferdeki dominant taksonlar; Alnus (\%2.6), Amaranthaceae (\%3.4), Betula (\%1.3), Carpinus (\%2.6), Corylus (\%23.1), Compositae (\%6.2), Cupressaceae (\%13.7), Fraxinus (\%1.7), Pinaceae (\%16.1), Plantago (\%1.1), Poaceae (\%17) ve Quercus (\%2.2) olarak belirlenmiştir. Meteorolojik parametrelerden sıcaklık ve rüzgar hızının genelde polen konsantrasyonu üzerine pozitif, yağışın ise negatif etki gösterdiği tespit edilmiştir. Araştırma sonuçları doğrultusunda Sinop için polen takvimi hazırlanmıştır.

Anahtar Kelimeler: Sinop, Atmosferik Polen, Volumetrik, Polen Takvimi, Türkiye

\section{Introduction}

It is known that $25-30 \%$ of the general population suffers from allergic diseases. In the last 20 years, it has been seen that the incidence of allergic diseases and asthma has increased due to industrialisation and rapid urbanisation especially in developed countries. Pollen and spore allergies are increasingly encountered in Turkey as in the whole world. Turkey has a very rich floristic structure due to its climatic conditions and geographic structure. The fact that $20 \%$ of 
these plant species have allergic properties increases the significance of pollen grain (Sin et al., 2007). Pollen grain of mostly anemophilous plant releases its pollen to the atmosphere depending on its specific pollination period. Their presence and dispersion in the atmosphere depends on meteorological factors such as temperature, wind speed, precipitation and relative humidity as well as the vegetation of the sampled area. Temperature, sunshine time and moderate winds increase the amount of pollen in the atmosphere, while light breezes and strong wind speeds, precipitation and relative humidity have a negative effect on pollen concentration. Rains and relative humidity wash away pollen grain or cause them to fall onto the ground without spreading in the air (Vega-Maray et al., 2003; Gemici, 2011).

Therefore, pollen concentrations in the atmosphere vary from year to year. Determination of daily, weekly, monthly and yearly changes of the amount of airborne pollen in cubic meter of air in the atmosphere of a region or city and preparation of pollen calendars could provide very useful data for physicians for treatment of allergy patients. If the types and concentration of the airborne pollen grain in the atmosphere are determined during periods when the symptoms of allergic diseases begin, intensify and end, better results may be obtained in diagnosis and treatment of pollen allergy. As in developed countries, the presence and concentration of allergen pollen grain in the atmosphere in many regions of Turkey has been analysed by using gravimetric and volumetric methods (Aytuğ et al., 1971; Potoğlu Erkara et al., 2007; Kızılpınar et al., 2012; Çeter et al., 2012; Öztürk et al., 2013; Cetin et al., 2015; Türkmen et al., 2018, Alan et al. 2018a; Özler, 2019, Kılıç et al., 2019; Alan et al., 2020; Güvensen et al., 2020, Çakır \& Doğan, 2020).

This study was conducted for the first time to determine the atmospheric pollen distribution of the province of Sinop where anemophilous plants occupy a broader area. Our study aims to contribute to national and international palynological databases. Another purpose of the study is to inform people who have allergies to pollen in the region where they need to take precautions in some periods and help physicians treat patients more quickly by looking at the prepared pollen calendar.

\section{Material and Methods}

Description of Study Area

The province of Sinop, where the survey was conducted, is located between the $41^{\circ} 12$ 'and $42^{\circ} 06^{\prime}$ northern latitudes and $34^{\circ} 14$ 'and $35^{\circ} 26^{\prime}$ eastern longitudes on the Boztepe cape and Peninsula, which extends most sharply towards the north of the Black Sea coastline. Sinop is surrounded by Kastamonu to the west, Çorum to the south, Samsun to the southeast, and the Black Sea to the north (Figure 1). Mountains lie parallel to the sea. As the mountains rising in the northwest approach the sea by $9-10 \mathrm{~km}$, they descent and form coastal plains. The highest hills of Sinop are located in Çangal in Ayancik and Dranaz in Boyabat. Temperature differences between the seasons are less variable. In the province, constant winds blowing throughout the year are effective. According to the 56-year average meteorological data in Sinop's centre, the annual rainfall regime is autumn, winter, spring, summer (AWS). For this reason, the Western Mediterranean Precipitation Regime is seen in Sinop (Akman, 2011; Canş1 Demir, 2018). Deciduous and coniferous trees predominate in forests in the higher parts of the province. There are scrub areas and some wetlands in the peninsula where the city centre is located and in some coastal areas. The dominant vegetation types are consist of Fagus orientalis, Carpinus betulus, $C$. orientalis, Quercus cerris subsp. cerris, $Q$. hartwisiana, Fraxinus angustifolius subsp. oxycarpa, Ulmus minor subsp. canescens, Acer trauvetteri, A. campestre, and Castanea sativa. Rhododendron luteum, Ilex colchica, Rubus canascens, Daphne pontica, Crataegus monogyna. Quercus ilex, Arbutus unedo, Phillyrea latifolia, Laurus nobilis, Myrtus communis subsp. communis, Spartium junceum, and Olea europaea var. sylvestris. Sarcopoterium spinosum, Quercus ilex, Laurus nobilis, Phillyrea latifolia, P.terebinthus, Arbutus unedo, Vitis sylvestris, Crataegus monogyna subsp. monogyna, Clematis vitalba, Hedera helix, Rubus sanctus, Ruscus acuelatus, Erica arborea, Cistus creticus, Cornus sanguinea subsp. australis, Cornus mas, Mespilus germenica, 
Corylus avellana ext. (Karaer \& Kılınç, 1993; Kilınç \& Karaer, 1995).

Acer platanoides, A. negundo, A. palmatum, Aesculus hippocastanum, Arbutus unedo, Betula alba, Celtis australis, Cercis siliquastrum, Cotinus cogyria, Eucalyptus camaldulensis, Eleagnus angustifolia, Fraxinus excelsior, Laurus nobilis, Malus floribunda, Olea europaea, Platanus orientalis, Robinia pseudoacacia, Salix babylonica, Salix caprea, Morus nigra, Washingtonia filifera, Abies nordmanniana, Chamaecyparis lawsoniana, Cupressus arizonica, $C$. sempervirens, Picea excels, $P$. pungens, Pinus nigra, Taxus baccata, Thuja orientalis, Juniperus horizontalis, Citrus spp. ext. are used for ornamental purposes on the university campus where the trap is located. Plants such as Corylus avellana, Juglans regia, Populus sp., Salix sp., are grown in the gardens of the houses, which are $300 \mathrm{~m}-10 \mathrm{~km}$ distance from the trap. In addition, Alnus, Carpinus, Cupressaceae, Quercus, Pinaceae and Poaceae taxa are widely found in natural areas.

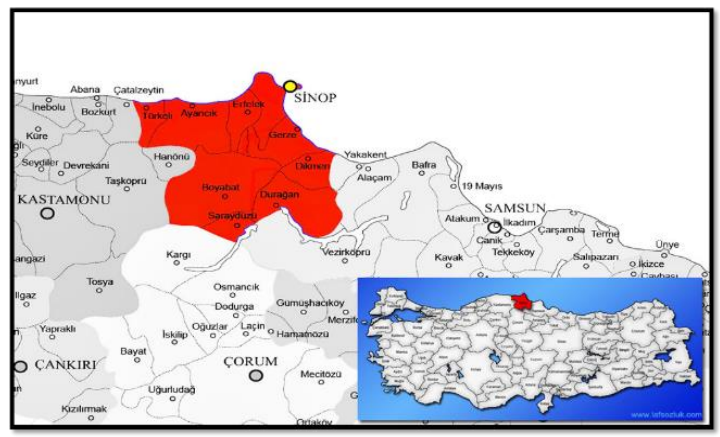

Figure 1. Map showing location of Sinop where the pollen survey was made

\section{Aeropalynological Survey}

The Burkard 7-day volumetric trap (Hirst, 1952) that was used in the sampling process was installed on a 10 meter high roof of a building in the campus of Sinop University in Korucuk between July 2010 and June 2012. Pollen grain in the air absorbed by the device mounted to the Melinex tape which was coated with a thin film of moviol (Baschong et al., 2001). After this, the tapes that were changed weekly were cut into seven daily pieces. Then, the pieces were mounted on microscope slides and were stained with glycerine jelly containing safranin. The diagnosis of airborne pollen grain and taking microphotographs were carried out by a digital camera attached on a Leica DM3000 microscope at magnification rates of $40 \mathrm{X}$ and $10 \mathrm{X}$. Identification of pollen grain was based on reference slides, the palynological literature, atlases and books (Aytuğ et al., 1971; Charpin \& Surinyach, 1974; Erdtman, 1957; 1969; Markgraf \& D'antoni, 1978; Moore \& Webb, 1983; Nilsson et. al., 1977; Kapp et al., 2000; Pehlivan, 1995; Punt et al., 2007; Hesse et al., 2009). Pollen grain was counted on the surface of 12 transverse bands by multiplying the conversion factor and expressed as the daily average of pollen grain per cubic meter of air (Lacey \& West, 2006). Procedures to sample and analyse pollen grain in this research were followed as recommended by the Spanish Aerobiological Network (REA: Red Española de Aerobiología; Galán et al., 2007). Pollen concentrations were converted to daily average concentrations (pollen grain $/ \mathrm{m}^{3}$ ). The main pollen seasons (MPS) of Alnus, Amaranthaceae, Betula, Carpinus, Compositae, Corylus, Cupressaceae, Fraxinus, Pinaceae, Plantago, Poaceae and Quercus taxa in the atmosphere were determined according to the 98\% method (Emberlin et al. 1993; Jato et al., 2006). According to this method, the pollen season was defined as the period in which $98 \%$ of the total catch occurred. The season started after the $1 \%$ level was reached and ended on the level of $99 \%$. In this study, the terminology adopted by Galán et al. (2017) was followed.

\section{Meteorological Data}

Daily and monthly meteorological data (average temperature, relative humidity, rainfall and wind speed) of Sinop's atmosphere for the years of 2010, 2011 and 2012 were supplied by the Turkish State Meteorological Service (Figure 2).

Statistical Analysis

To find possible correlations between the meteorological parameters and daily pollen concentrations of 12 dominant taxa (Alnus, Amaranthaceae, Betula, Carpinus, Compositae, Corylus, Cupressaceae, Fraxinus, Pinaceae, Plantago, Poaceae, Quercus) detected in the atmosphere, this study used Spearman's Correlation test in the 
SPSS version 21.0 software (IBM SPSS Statistics for Windows, Version 21.0. Armonk, NY: IBM Corp. Armonk) (Table 1).

\section{Results}

A total of 93.414 pollen grain belonging to 61 plant taxa were determined in the analyses carried out in the province of Sinop in a 24month period. Of these taxa, 37 were trees, 23 were weeds and Grasses (Poaceae). 69.5\% of these pollen grain belonged to tree taxa,
$17.1 \%$ belonged to Poaceae, and $13.4 \%$ belonged to weeds (Figure 3).

8,325 pollen grain belonging to 28 taxa in the year 2010, 58,038 pollen grain belonging to 38 taxa in the year 2011 and 27,051 pollen grain belonging to 39 taxa in the year 2012 were determined in the atmosphere. The lowest pollen concentration was counted in December 2010 with 36 pollen grain, and the highest concentration was counted in May 2011 with 15,454 pollen.

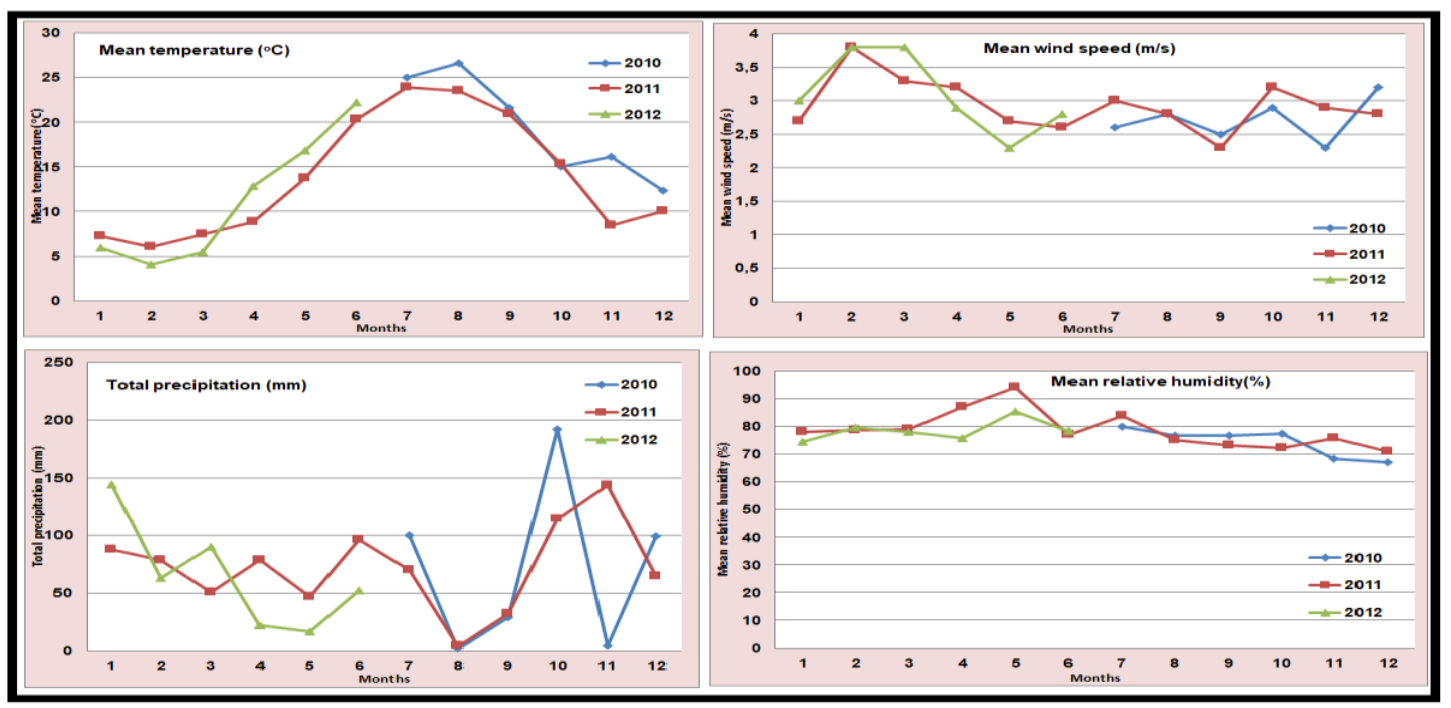

Figure 2. Graphs showing average monthly changes of meteorological factors

Table 1. Spearman's correlation analysis between daily total pollen concentration of dominant plant taxa and meteorological data ( $r$ value)

\begin{tabular}{lcccc}
\hline Plant taxa & $\begin{array}{c}\text { Daily mean } \\
\text { temperature }\end{array}$ & $\begin{array}{c}\text { Daily total } \\
\text { precipitation }\end{array}$ & $\begin{array}{c}\text { Daily mean } \\
\text { wind speed }\end{array}$ & $\begin{array}{c}\text { Daily relative } \\
\text { humidity }\end{array}$ \\
\hline Alnus & -0.187 & $-0.393^{*}$ & 0.224 & 0.115 \\
\hline Amaranthaceae & $0.408^{* *}$ & -0.120 & 0.508 & 0.563 \\
\hline Betula & -0.72 & 0.220 & 0.348 & $0.448^{* *}$ \\
\hline Carpinus & -0.285 & -0.166 & -0.103 & -0.202 \\
\hline Compositae & $0,798^{* *}$ & 0.111 & $0.679^{* *}$ & $0.622^{* *}$ \\
\hline Corylus & $0.721^{* *}$ & 0.254 & $0.732^{* *}$ & $0.855^{* *}$ \\
\hline Cupressaceae & 0.225 & 0.172 & $0.786^{* *}$ & $0.504^{* *}$ \\
\hline Fraxinus & $0.658^{* *}$ & 0.134 & 0.350 & $0.708^{* *}$ \\
\hline Pinaceae & $0.645^{* *}$ & 0.165 & $0.628^{* *}$ & $0.743^{* *}$ \\
\hline Plantago & $0.581^{* *}$ & 0.270 & $0.554^{* *}$ & $0.588^{* *}$ \\
\hline Poaceae & $0.607^{* *}$ & 0.310 & $0.581^{* *}$ & $0.710^{* *}$ \\
\hline Quercus & $0.741^{* *}$ & 0.240 & $0.737 *$ & $0.786^{* *}$ \\
\hline Correlation is significant at the 0.05 level (P-value). $* *$ Correlation is significant at the 0.01 level (P-value)
\end{tabular}




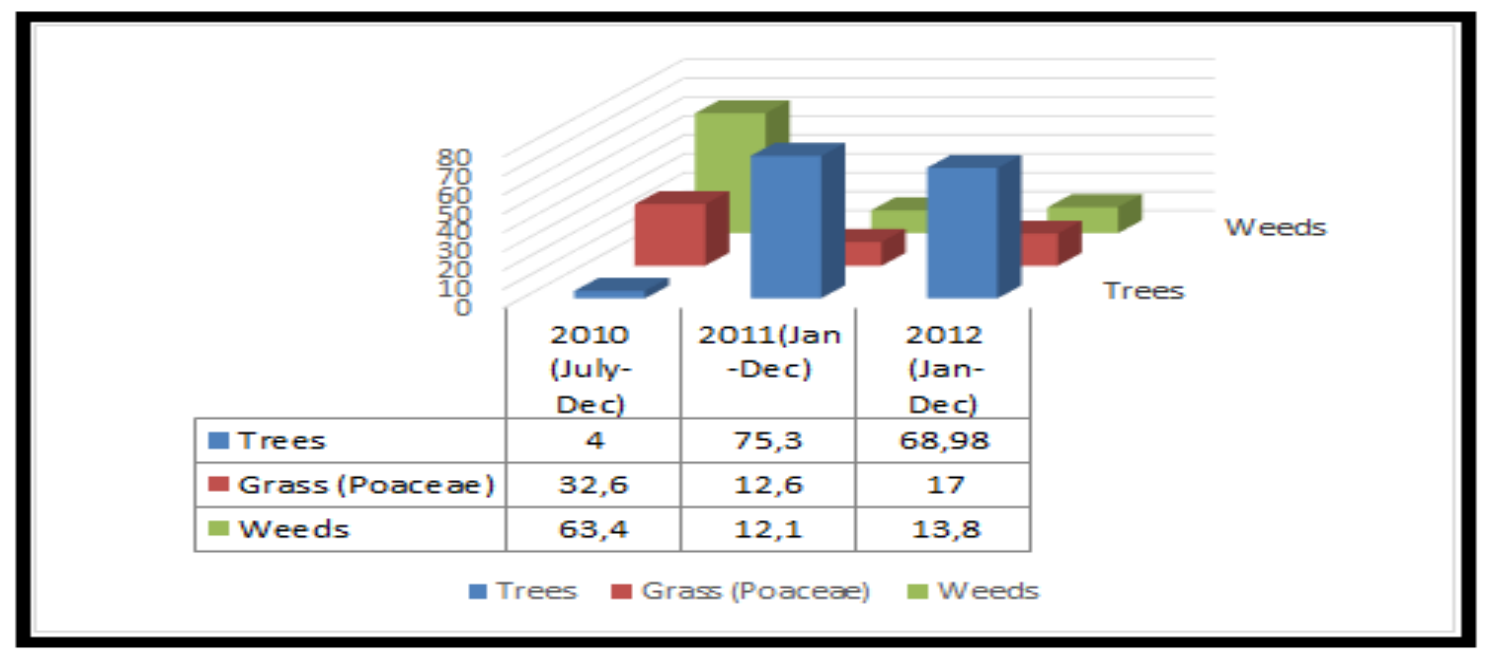

Figure 3. A percentage of annual total amount of pollen grain belonging to Trees, Grasses (Poaceae) and Weeds recorded in the atmosphere of Sinop

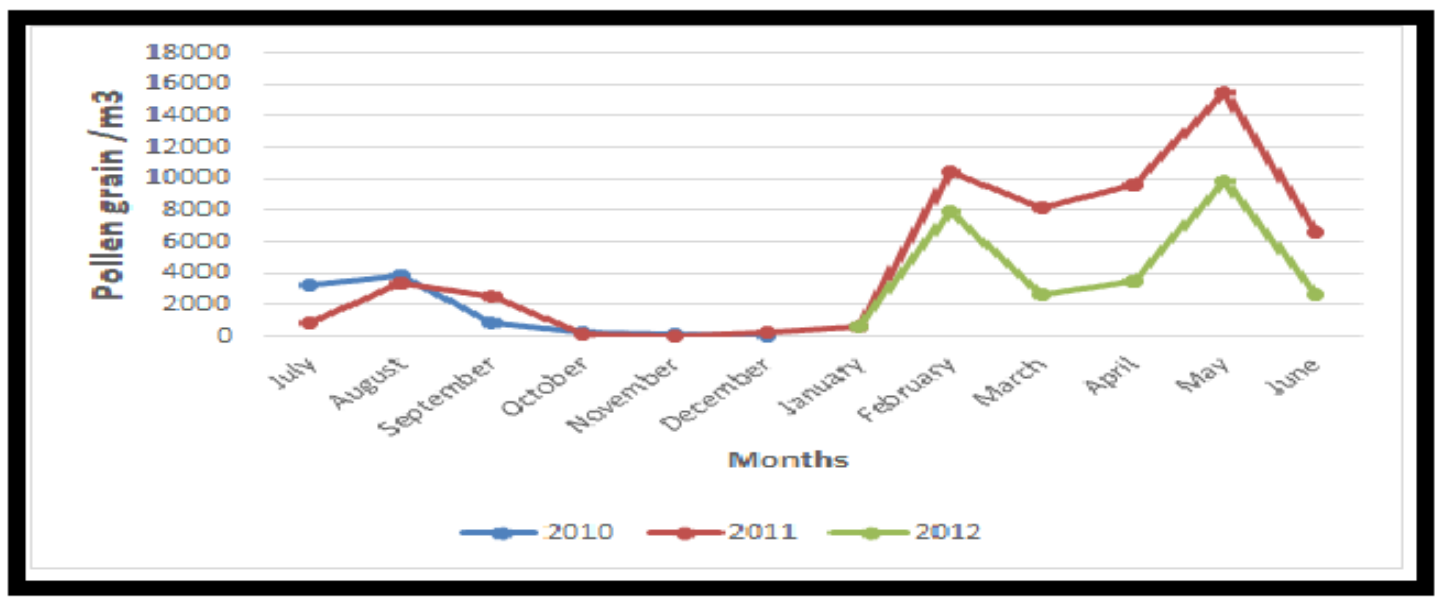

Figure 4. Monthly total pollen concentrations in the atmosphere of Sinop (2010-2012)

grain (Figure 4). In the year 2010 (JulyDecember), the pollen grain of weeds $(63.4 \%)$ was the largest contributors to the total pollen grain, followed by Poaceae (32.6\%) and trees (4\%). In the years 2011 (January-December) and 2012 (January-June), the ranking from the highest to the lowest was as pollen grain of trees $(75.3 \%, 68.98 \%)$, Poaceae $(12.6 \%, 17 \%)$ and weeds $(12.1 \%, 13.8 \%)$ (Figure 3). Alnus (2.6\%), Betula (1.3\%), Carpinus (2.6\%), Corylus (23.1\%), Cupressaceae (13.7\%), Fraxinus (81.7\%), Pinaceae (16.1\%), Quercus (2.2\%), Amaranthaceae (3.4\%), Compositae $(6.2 \%)$, Plantago $(1.1 \%)$ and Grasses (Poaceae) (17\%) were recorded as the dominant taxa in the atmosphere based on their pollen grain during the studied period. There were significant increases in the pollen grain of Corylus and Fraxinus in February,
Alnus and Carpinus in March, Cupressaceae in April and Pinaceae and Poaceae in May (Figure 5).

The highest average temperature was measured in August in 2010, and the lowest average temperature was measured in February in 2012 throughout the studied period. The hottest period was recorded in May-October, and the coldest period was in January-March. The average wind speed was the highest in February in 2011 and February and March in 2012, and the lowest wind speed was in September in 2012. The total rainfall was the highest in October in 2010, and the lowest total rainfall was in August in the same year. The average relative humidity was measured as the maximum in May in 2011, and the minimum relative humidity was measured in December in 2010 (Figure 2). 
According to the Spearman's correlation test results used to determine the relationship between the main pollen seasons of 12 dominant pollen taxa detected in the atmosphere and meteorological factors, the pollen grain of Amaranthaceae, Compositae, Corylus, Fraxinus, Pinaceae, Plantago, Poaceae and Quercus showed a positive correlation with daily average temperature. There was a negative correlation between the pollen grain of Alnus and total daily rainfall. The pollen grain of Compositae, Corylus, Cupressaceae, Pinaceae, Plantago, Poaceae and Quercus displayed a positive correlation with average daily wind speed. Similarly, it was determined that there were positive correlations between the pollen grain of Betula, Compositae, Corylus, Cupressaceae, Fraxinus, Pinaceae, Plantago, Poaceae and Quercus and relative humidity (Table 1).

\section{Discussion}

In this study conducted for the first time in Sinop, Korucuk district, 61 pollen taxa were identified from Sinop's atmosphere (Çeter et al., 2014). $68.98 \%$ of the pollen were found to belong to trees, $17 \%$ belonged to Poaceae, and $13.8 \%$ belonged to weeds taxa. Similar results were found in the studies conducted in the atmospheres of Kastamonu which is located close to Sinop and Gümüşhane which is located in the inner part of the Black Sea Region (Çeter et al., 2012, Türkmen et al. 2018). In a later study about Sinop's atmosphere that was conducted by Canş1 Demir (2018) for the years 2016 and 2017, 119,361 pollen grain belonging to a total of 87 taxa were identified, among which 49 were arboreal taxa (71.12\%), 37 were non-arboreal taxa $(23.65 \%)$, and $5.29 \%$ were Poaceae. The reason for the differences in the numbers of taxa and the amounts of pollen grain detected in this study and previous studies may be due to changes in the meteorological factors of the studied periods and the location and height where the pollen traps were placed (Lehtimäki et al., 1991; Chakraborty et al., 2001).

In 2010, since the airborne pollen study began in July after the end of the flowering period of the trees, pollen grain belonging to trees $(4 \%)$ was found to be very low. On the other hand, pollen grain of weeds plants (63.4\%) and Poaceae (32.6\%) was more likely to participate in the atmosphere. When the years of 2011 and 2012 were compared, it was recorded that the pollen grain belonging to trees, Poaceae and weeds was ranked as the most common in the atmosphere respectively. The reason for the low rate of pollen grain in weeds plants compared to 2011 was that the study ended in June, which was the beginning of the

Table 2. Main pollen season (MPS) for the dominant taxa ( $\geq 1 \%)$ in the atmosphere of Sinop

\begin{tabular}{|c|c|c|c|c|}
\hline \multirow[t]{2}{*}{ Dominant plant taxa } & \multicolumn{2}{|c|}{ Main Pollen Season } & \multirow{2}{*}{$\begin{array}{c}\text { MPS } \\
\text { length/Day }\end{array}$} & \multirow{2}{*}{$\begin{array}{c}\text { Max. daily } \\
\text { concentration } \\
\text { (pollen/m3 ) / date }\end{array}$} \\
\hline & Start & End & & \\
\hline Alnus & $13 \mathrm{March}$ & 9 April & 28 & $212(25 / 03 / 2012)$ \\
\hline Amaranthaceae & 12 July & 12 October & 124 & $148(8 / 09 / 2011)$ \\
\hline Betula & 1 April & 27 May & 57 & $56(14 / 04 / 2012)$ \\
\hline Carpinus & $18 \mathrm{March}$ & 24 April & 38 & $295(26 / 03 / 2011)$ \\
\hline Compositae & 14 August & 28 September & 46 & $420(26 / 08 / 2019)$ \\
\hline Corylus & 13 February & $30 \mathrm{March}$ & 43 & $1079(23 / 02 / 2012)$ \\
\hline Cupressaceae & 11 April & 1 June & 52 & $991(19 / 04 / 2011)$ \\
\hline Fraxinus & 3 January & 22 March & 80 & $85(22 / 02 / 2011)$ \\
\hline Pinaceae & 11 May & 27 June & 48 & $991(16 / 05 / 2011)$ \\
\hline Plantago & 2 July & 25 August & 55 & $55(15 / 07 / 2010)$ \\
\hline Poaceae & 12 May & 23 September & 135 & $550(23 / 05 / 2012$ \\
\hline Quercus & 16 April & 27 May & 42 & $137(19 / 04 / 2012)$ \\
\hline
\end{tabular}




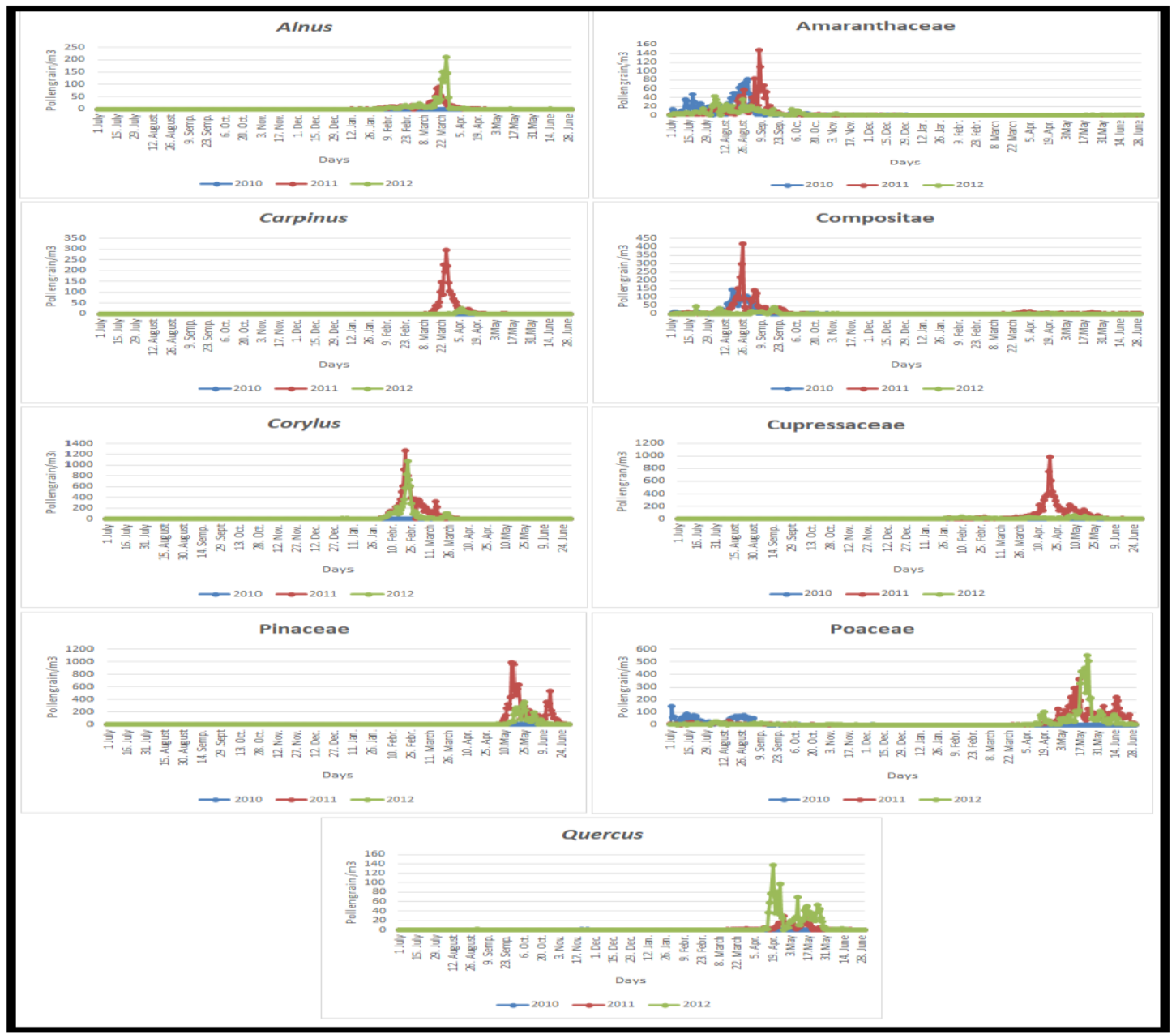

Figure 5. Daily pollen concentration of most dominant taxa $(\geq 2 \%)$ in the atmosphere of Sinop (2010-2012)

flowering period of weeds in 2012 (Figure 3). The maximum pollen concentration during the airborne study was determined in the period between February and May (Figure 4). In the period, it was observed that trees taxa which were producing more pollen such as Alnus, Corylus, Carpinus, Cupressaceae, Fraxinus, Pinaceae, Populus, Quercus and herbaceous taxa such as Compositae and Poaceae contributed more pollen to the atmosphere (Figure 6). Meteorological conditions such as temperature, precipitation, relative humidity and wind speed affect the amount of pollen in the atmosphere. In this context, when we look at meteorological factors in the period between February and May, while the average monthly temperature in 2010 was higher than those in 2011 and 2012 , the average monthly wind speed was about the same. The average monthly total precipitation and average monthly relative humidity were slightly higher in 2011 than those in 2010 and 2012 (Figure 2, Figure 5).

The pollen grain of Corylus was overwhelmingly the most prevalent in the atmosphere, representing $23.1 \%$ among all other pollen taxa (Table 2, Figure 6). Its pollen grain was observed from January to the first week of May in 2011 and 2012 until the end of March and reached the maximum level in the 3rd week of February. The main pollen season was detected between February 13 and March 30 (Table 2). The taxa of Corylus is cultivated for its fruits in the province of Sinop and frequently seen in forested areas. The fact that Corylus cultivation was being performed close to the area where the trap was placed may have been the reason why the pollens were seen more in the atmosphere. In a study conducted for the period of 2016- 
2017 , its pollen was detected by a very small amount (1.21\%) (Canşı Demir, 2018). The reason for these differences may be localisation of traps, height and meteorological factors (Table 2, Figure 5). The Corylus pollen grain rate was identified as $0.2 \%$ in the atmosphere of Kastamonu by Çeter et al. (2012), as $8.17 \%$ in the atmospheres of Aktoprak and Beşirli (Trabzon) by Yavru (2000), as $2.7 \%$ in the atmosphere of Gerze (Sinop) by Özler (2019). It was seen that the results of the aforementioned studies were lower than those in our study. The taxon of Corylus as in other members family of Betulaceae produces highly allergenic pollen grain (Alan et al., 2010).

Poaceae (17\%) were observed to have the second highest amount of pollen taxon in the atmosphere. Its pollen were observed in all months from January on. The main pollen season was between May 12 and September 23 and covered a long period. The maximum pollen concentration of this taxon was monitored in the 4th week of May (Table 2, Figure 5, Figure 6). These taxa's pollen grain was recorded as $5.29 \%$ in the later study conducted in 2016-2017(Canş1 Demir, 2018). While in some studies conducted in the Black Sea Region, the amount of Poaceae pollen was similar to our results (Kaya \& Aras, 2004; Serbes and Kaplan, 2014), the results of some studies were found to be on a lower rate from our results (Çeter et al., 2012; Kaplan \& Özdoğan, 2015; Türkmen et al., 2018, Alan and Kaplan, 2018b; Özler 2019). The pollen grain of this taxon causes very significant allergic reactions as shown with research and tests (Chapman, 1986; Nardi et al., 1986).

Pinus brutia, $P$. sylvestris and $P$. nigra which constitute forest vegetation in Sinop and plants which are used in plantations in coastal areas such as $P$. pinaster and Abies nordmanniana that can produced 10-15 billion pollen grain from a single tree into the atmosphere and the pollen grain of these plants belonging to the family of Pinaceae was the third most abundant taxa in the air of Sinop $(16.1 \%)$ (Table 2, Figure 5, Figure 6). Pinaceae pollen grain was seen in all months, and they reached the maximum level in the 3rd week of May. The main pollen season of this taxon which has a little allergic effect was between 11 May and 27 June (Table 2, Figure 5) (Sin et al., 2007; Ogren, 2000). In a study in Sinop and in Gerze, this taxon's pollen was determined to have rates of $15.51 \%$ and 16.9\% (Canşi Demir, 2018, Özler, 2019). The results of the other airborne studies in the same region showed that the pollen grain of Pinaceae was among the most common and dominant pollen taxa (Çeter et al., 2012; Alan and Kaplan, 2018b; Türkmen et al., 2018).

The pollen grain of Cupressaceae (13.7\%) was the fourth most abundant in the air of Sinop. Their pollen grain was continuously observed in the atmosphere throughout the two years, except in December. The members of this taxon are often used in urban landscaping and produce large amounts of pollen due to wind pollination. Therefore, their pollen was seen more in the atmosphere. The main pollen season was between 11April and 1 June. Their pollen concentration reached the maximum level in the 2 nd week of April (Table 2, Figure 5, Figure 6). In the studies, the ratio of this taxon was found to be higher than that in this study $(32.59 \%, 60.2 \%)$ (Canş1 Demir, 2018, Özler 2019). Guardia et al. (2006) stated that the pollen grain of the Cupressaceae family is among the most prominent allergens seen in the atmosphere of Mediterranean countries in recent years.

The pollen grain of Compositae (except the genera Artemisia and Centaurae) which is among the weed taxa was the fifth most abundant taxa during the studied period $(6.2 \%)$. The main pollen season of this taxon, whose pollen was seen in the atmosphere in all months, was between 14 August and 28 September. Pollen concentration reached the maximum in the last week of August (Table 2, Figure 5, Figure 6). Canşı Demir (2018) reported that the pollen grain of Compositae was recorded as $0.43 \%$ in the years 2016 and 2017. This was because the pollen of the Artemisia, Centaurea, Ambrosia, Xanthium and Lactuceae taxa were separated from the Compositae family in her study. The researcher observed that Compositae pollen attacks occurred firstly in late spring and early summer, and secondly in late summer and autumn (August-October). The ratio of this taxon whose pollen has allergenic effect was determined as as $0.48 \%$ in Çanakkale (Güvensen et al., 2005), as $1.5 \%$ in 
Kastamonu (Çeter et al., 2012), as $4.23 \%$ in Bartın (Kaya and Aras, 2004). Ogden (2000) and Singh et al. (2008) stated that the pollen grain of Artemisia from this family, had been a cause of severely allergic diseases. In this survey, the amount of pollen grain of Artemisia was detected to be very low in the atmosphere of Sinop $(0.6 \%)$.

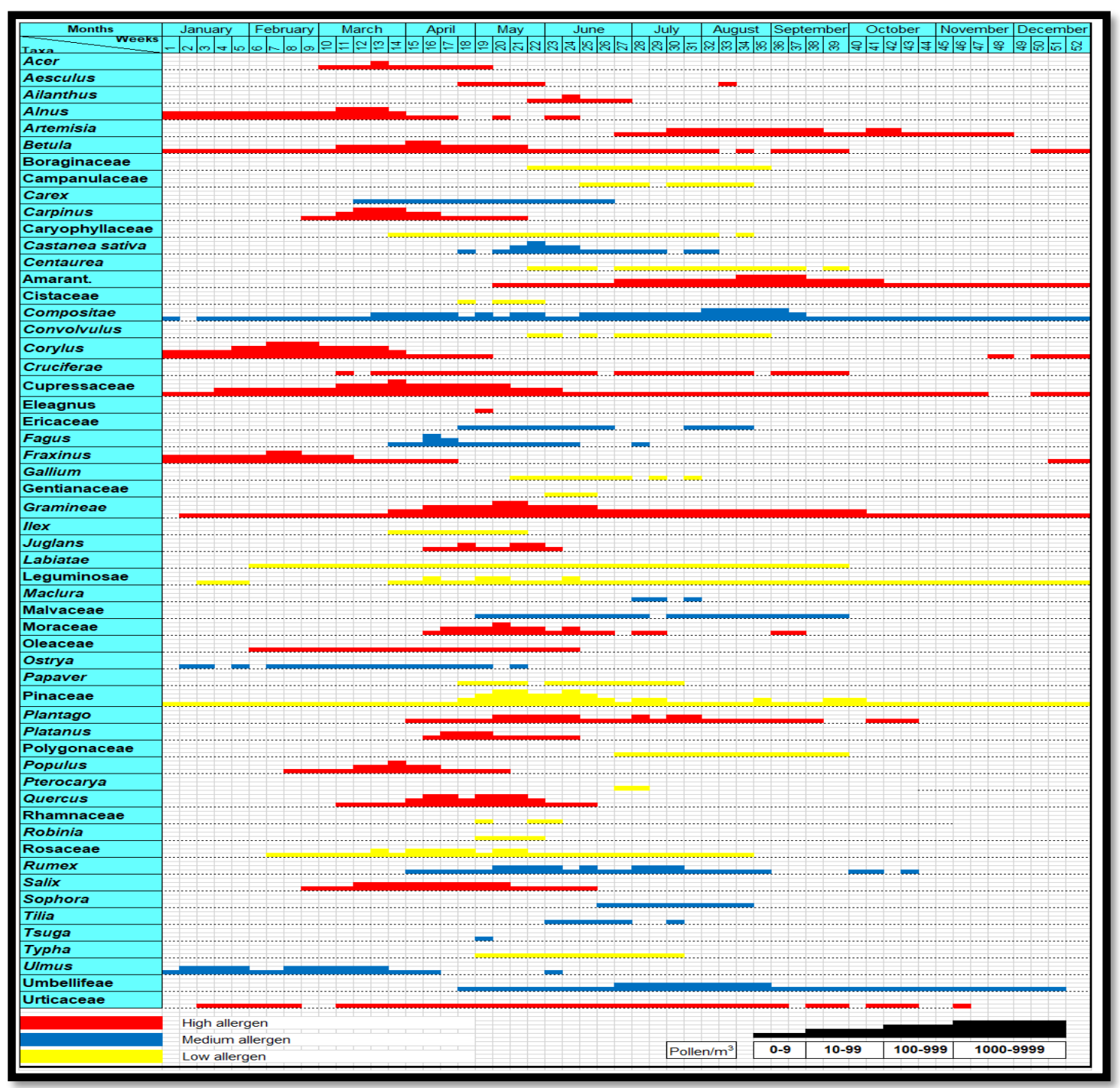

Figure 6. Pollen calendar prepared for the pollen grain detected in the atmosphere of Sinop in the years 2010 and 2012

The pollen of the Amaranthaceae family of herbaceous and low shrubs found in roadsides, vacant lands and cultural areas made up $3.4 \%$ of the total pollen grain captured in Sinop's atmosphere. Their pollen grain was observed from May to the end of December and showed a significant increase in August. The main pollen season was between July 12 and November 12, and pollen was observed for a long period in the atmosphere. The maximum pollen concentration was recorded in the second week of September (Table 2, Figure 5, Figure 6). In a study conducted in the year 20162017, the ratio of this taxon was determined as $4.71 \%$ (Canşi Demir 2018). While the amounts of pollen grain belonging to this taxon were detected lower in Kastamonu (1.68\%), Karabük (1.45\%), Düzce $(4.49 \%)$, Zonguldak (1.51\%) and Gümüşhane (1.5\%) than the results of this study, they were assessed higher in Samsun (5.66\%) than those in this study (Çeter et al., 2012; Kaplan \& Özdoğan, 2015; Serbes \& Kaplan, 2014; Alan 
\& Kaplan, 2018b; Türkmen et al., 2018; Erkan et al., 2006). The members of the family of Chenopodiaceae were transferred to the family of Amaranthaceae according to their recent systematic studies. The pollen grain of Amaranthus and Chenopodium has been shown as some of the most significant important allergy factors for India (Singh \& Shahi, 2008).

While Alnus (2.6\%) and Carpinus $(2.6 \%)$ from the family of Betulaceae which are the most common in forests and roadsides were the seventh most abundant pollen taxa in the atmosphere, the pollen grain of Quercus $(2.2 \%)$ was seen as the eighth. Betula $(1.3 \%)$, which is used only for ornamental purposes in the rectorate campus of Sinop University, is not in the natural flora of the province of Sinop, and Fraxinus (1.7\%) is commonly used in park and garden afforestation. Therefore, the pollen grain of these taxa and Plantago $(1.1 \%)$ was detected at very low rates (Table 2 , Figure 5, Figure 6). The pollen contents of the aforementioned taxa in a next study were determined as $2.24 \%, 1.43 \%, 2.76 \%, 0.13 \%$, $1.33 \%$ and $0.72 \%$, respectively (Canş1 Demir, 2018). Pollen of Alnus was determined higher ratio $(8.3 \%)$ in the atmosphere of Gerze by Özler (2019) than this study. In a study carried out in Gümüşhane, Alnus, Carpinus and Fraxinus pollen grain rates were lower than those in this study, whereas the rates of Betula and Quercus pollen were higher. In the same study, the pollen of Plantago was found in almost the same rate (Türkmen et al., 2018). Çeter et al. (2012) found that the ratio of the pollen grain of Carpinus was the same as this study, while Fraxinus and Plantago pollen ratios were lower than those in this study. Besides, Betula and Quercus pollen ratios were higher in the atmosphere of Kastamonu than in the atmosphere of Sinop. During the study period, the pollen grain of Alnus in January-June, pollen grain of Carpinus in March-May, pollen grain of Fraxinus in January-April, pollen grain of Betula in every month in a small amount, pollen grain of Plantago in April-October as in Poaceae was found in the atmosphere in the studied period. The main pollen season was March 13- April 9 for Alnus and March 18 - April 24 for Carpinus (Table 2). Many researchers have reported that pollen from these taxa causes respiratory system diseases such as asthma and hay fever (Chapman \& Williams, 1984; Möller et al., 1986, Olei et al., 1986, Pehlivan, 1995, Ogren, 2000; Sin et al., 2007).

A different relationship was found between pollen concentration during the mean pollen season of the dominant taxa detected in Sinop's atmosphere and meteorological parameters (temperature, precipitation, wind speed, relative humidity) by means of a Spearman's correlation test. Generally, it was emphasised that temperature and wind speed had a positive effect on pollen concentration, while rainfall and relative humidity had a negative effect (Rodríguez-Rajo et al., 2003). In this study, a positive correlation was determined between daily average relative humidity and the pollen grain of Betula, Compositae, Corylus, Cupressaceae, Fraxinus, Pinaceae, Plantago, Poaceae and Quercus (Table 1). Similar results have been also found by some researchers (Çeter et al., 2012; Perveen et al., 2015; Türkmen et al., 2018). It was determined that temperature and wind speed had a positive effect on pollen concentration in the period of study.

\section{Conclusions}

Most of the total pollen detected in the atmosphere of Sinop in the years 2010-2012 consisted tree taxa. This result was compatible with the vegetation of Sinop, 63\% of which consists of forest areas. The obtained data of this study showed that the pollen grain peaked in February (Alnus, Corylus, Fraxinus), May (Cupressaceae, Pinaceae, Quercus) and August (Amarantaceae, Compositae), and during these periods of peak pollen distribution. Additionally, a pollen calendar was prepared for Sinop using the data obtained during the two-year period, in order to enable patients who are sensitive to pollen to take preventive measures and physicians to perform appropriate treatments for patients (Figure 6). Since pollen peaks vary according to meteorological factors, aeropalynological studies need to be continued for many years for reliable modelling and in relation to the need to develop site-specific forecast models.

\section{Funding}

This study was produced from the supported project 109 S265 by TUBITAK 
within the scope of COST program ES0603 Action and Ankara University Office of Scientific Research Projects (BAP14H0430001 HDP).

\section{References}

Akman, Y. (2011). Iklim ve biyoiklim (1. bask1). Ankara: Palme Yayıncılık.

Alan, Ş., Sarışahin, T., Şahin, A.A., Kaplan, A. \& Pinar, N.M. (2020). An assessment of ragweed pollen and allergen loads in an uninvaded area in the Western Black Sea region of Turkey. Aerobiologia, 36, 183-195.

Alan, Ş, Sarışahin, T. \& Kaplan, A. (2018a). Changes of Artemisia pollen concentration in Zonguldak atmosphere. Communications Faculty of Sciences University of Ankara Series C-Biology, 27(2),150-155.

Alan, Ş. \& Kaplan, A. (2018b). Comparison of two aerobiological stations data in Zonguldak. Communications Faculty of Sciences University of Ankara Series C-Biology, 27(2), 132-140.

Alan, Ş., Yıldırım, Ö. \& Pınar, M. (2010). Türkiye Betula (huşağac1) ve Corylus (fındık) polenlerinde yer alan nişasta taneleri. Asthma Allergy Immunol. 8, 108111.

Aytuğ, B., Aykut, S, Merev, N. \& Edis, G. (1974). Belgrad Ormanı'nın ve İstanbul Çevresi Bitkilerinin Polinizasyon Olayını Tesbiti ve Değerlendirilmesi. Ankara: TBTAK Yayınları, Say1 221, TOAG Seri No: 29.

Aytuğ B. (1971). İstanbul Çevresi Bitkilerinin Polen Atlast. Kurtulmuş Matbaası. İstanbul: İstanbul Üniversitesi Yayın No:1650.

Baschong, W., Suetterlin, R. \& Laeng, R.H. (2001). Control of autofluorescence of archival formaldehyde-fixed, paraffin embedded tissue in confocal laser scanning microscopy (CLSM). Journal of Histochemistry \& Cytochemistry, 49, 1565-1571.

Canşı Demir, C. (2018). Sinop ili (merkez) atmosferindeki polenlerin araştırılması, Yüksek Lisans Tezi. Sinop Üniversitesi Fen Bilimleri Enstitüsü, Sinop.

Chakraborty, P., Bhattacharya, S.G., Chowdhory, I., Majumdar, M.R. \& Chanda, S. (2001). Differences in concentrations of allergenic pollens and spores at different heights on an agricaltural form in Vest Bengal, India. Annals of Agricultural and Environmental Medicine., 8, 123-130.

Chapman, I.A. (1986). Aeroallergens of southeastern Missouri, U.S.A., Grana, 25, 235246.

Chapman, J.A. \& Williams, S. (1984). Aeroallergens of the southeast Missouri area,
A report of skin test frequenchies and air sampling data. Annals of Allergy, 52, 411-417.

Charpin, J., Srinyach, R. \& Frankland, AW. (1974). Atlas of European allergenic pollens. Paris: Sandoz Edition.

Çakır, N. \& Doğan, C. (2020). Relationship between pollen counts and weather variables in the atmosphere of Mersin Province on the Eastern Mediterranean Coast of Turkey Turkish Journal of Botany, 44, 526-538.

Çeter, T., Pınar, N.M., Bayar, E., Akdoğan, S., Altuner, E.M. \& Özler, H. (2014). Sinop atmosferi iki yıllık alerjik polen takvimi. XXI Ulusal Alerji ve Klinik İmmünoloji Kongresi, 25-29 Ekim, Bodrum.

Çeter, T., Pınar, N.M., Güney, K., Yıldız, A., Așcı, B. \& Smith, M. (2012). A 2-year aeropalynological survey of allergenic pollen in the atmosphere of Kastamonu, Turkey. Aerobiologia, 28, 355-366.

Çetin, E., Altunoğlu, M.K., Akdoğan. G.E. \& Akpınar, S. (2015). Ardahan ili atmosferik polenlerinin belirlenmesi. Kafkas Üniversitesi Fen Bilimleri Enstitüsü Dergisi. 8(2), 80-94.

Emberlin, J., Savage, M. \& Jones, S. (1993). Annual variations in grass pollen seasons in London 1961-1990: Trends and forecast models. Clinical and Experimental Allergy, 23, 911--918.

Erdtman, G. (1969). Handbook of Palynology. New York: Hafner Publishing Co.

Erdtman, G. (1957). Pollen and Spore Morphology/Plant Taxonomy. Sweden: Almquist and Wiksells.

Erkan, M.L., Çeter, T., Atıcı, A.G., Özkaya Ş., Alan, Ş., Tuna, S. \& Pınar, N. M. (2006). Samsun ilinin polen ve spor takvimi. XIV. Ulusal Allerji ve Klinik İmmünolojik kongresi. Side, Antalya.

Galán, C., Ariatti, A., Bonini, M., Clot, B., Crouzy, B., Dahl, A., Fernandez-Gonzalez, D., Frenguelli, G., Gehrig, R. \& Isard, S et al. (2017). Recommended terminology for aerobiological studies Aerobiologia, 33, 293295.

Galán, C., Cariñanos, P., Alcázar, P. \& Dominguez-Vilches, E. (2007). Spanish Aerobiology Network (REA) Management and Quality Manual. Cordoba, Spain: Servicio de Publicaciones Universidad de Córdoba.

Gemici, Y. (2011). Atmosferik koşulların polen dağılımına etkisi. Türkiye Klinikleri J AllerjiSpecial Topics, 4(1), 31-37.

Guardia, C., Alba, F., Linares, C. \& Lugilde, D. (2006). Aerobiological and allergenic analysis of Cupressaceae Pollen in Granada (Southern Spain). Journal of Investigational Allergology and Clinical Immunology, 16 (1), 24-33. 
Güvensen, A., Uğuz, U., Altun, T., Eşiz Dereboylu, A.\& Şengonca Tort, N. (2020). Aeropalynological survey in the city center of Aydin (Turkey). Turkish Journal of Botany, 44(5), 539-551.

Güvensen, A., Uysal, I., Çelik, A. \& Öztürk, M. (2005). Analysis of arrborne pollen fell in Çanakkale, Turkey. Pakistan Journal of Botany, 37(3), 507-518.

Hesse, M., Halbritter, H., Zetter, R., Weber, M., Buchner, R., Frosch-Radivo, A. \& Ulrich, S. (2009). Pollen terminology: An Illustrated Handbook. New York: Springer.

Hirst, J.M. (1952). An automatic volumetric spore trap. Annals of Applied Biology, 39, 257-265.

Jato, V., Rodríguez-Rajo, F.J., Alcázar, P., De Nuntiis, P., Galán, C. \& Mandrioli, P. (2006). May the definition of pollen season influence aerobiological results? Aerobiologia, 22, 1325.

Kapp, R.O., Davis, O.K. \& King, J.E. (2000). Pollen and Spores ( $2^{\text {nd }}$ edition). Texas: AASP Foundation, Texas A\&M University, College Station.

Kaplan, A. \& Özdoğan, Y. (2015). Seasonal variations of airborne pollen grains in Karabük, Turkey. Karaelmas Science and Engineering Journal, 5(2), 1-13.

Karaer, F. \& Kılınç, M. (1993). Sinop yarımadasının florası. Turkish Journal of Botany, 17, 5-20.

Kaya, Z. \& Aras, A. (2004). Airborne pollen calendar of Bartın, Turkey. Aerobiologia, 20, 63-67.

Kılınç M. \& Karaer, F. (1995). Sinop yarımadasının vejetasyonu. Turkish Journal of Botany, 19, 107-124.

Kılıç, M., Altunoğlu, M.K., Akpınar, S., Akdoğan G.E. \& Taşkın, E. (2019). Relationship between airborne pollen and skin prick test results in Elazığ, Turkey. Aerobiologia, 35, 593-604.

Kızılpınar, I., Doğan, C., Artaç, H., Reisli, I. \& Pekcan, S. (2012). Pollen grains in the atmosphere of Konya (Turkey) and their relationship with meteorological factors, in 2008. Turkish Journal of Botany, 36, 344-357.

Lacey, M.E. \& West, J.S. (2006). Pollen and spore counts in: The Air Spora. A manuel for catching and identifying airborne biological particles. New York: Springer.

Lehtimäki, A.R., Kalvikko, A., Kupias, R., Mäkinen, Y. \& Pohjola, A. (1991). Significance of sampling height of airborne particles for aerobiological information. Allergy, 46(1), 68-76.
Markgraf, V. \& D’Antoni, H.L. (1978). Pollen Flora of Argentina. Tucson, Arizona: The University of Arizona Press.

Moore, P.D. \& Webb, J.A. (1983). An Illustrated Guide to Pollen Analysis. London: Hodder and Stoughton.

Möller, C., Dreborg, S., Lanner, A. \& Björksten, B. (1986). Oral immunotheraphy of children with rhinoconjunctivitis due to birch pollen. Allergy, 41, 271-279.

Nardi, G., Demasi, O., Marchegioni, A., Pierdomerico, R., Mincigrucci, G., Romano, B., Frenguelli, G. \& Bricchi, E. (1986). A Study on airborne allergenic pollen content in the atmosphere of Ascoli Piceno. Annals of Allergy, 57, 193-197.

Nilsson, S., Praglowski, J. \& Nilsson, L. (1977). Atlas of Airborne Pollen Grains and Spore in Nothern Europe. Stockholm: Verlag Natur och Kultur.

Ogren, T.L. (2000). Allergy-Free Gardening: The revolutionary guide to healthy landscaping. Berkeley Toronto: Ten speed press.

Olei, H.D., Spieksma, F.T.M. \& Bruynzeel, P.L.B. (1986). Birch pollen asthma in the Netherland. Allergy, 41, 435-441.

Öztürk, M., Güvensen, A., Gucel, S. \& Altay, V. (2013). An overview of the atmospheric pollen in Turkey and the Northern Cyprus. Pakistan Journal of Botany, 45, 191-195.

Özler, H. (2019). A study on airborne pollen grains in the atmosphere of Gerze (Sinop,Turkey) and their relationship with meteorological conditions. Phytologia Balcanica, 25, 249-260.

Pehlivan, S. (1995). Türkiye'nin Allerjen Polenleri Atlası. Ankara: Ünal Basımevi.

Perveen, A., Khan, M., Zeb, S. \& Imam, A. (2015). Impact and correlation of environmental conditions on pollen counts in Karachi, Pakistan. Iranian Journal of Allergy, Asthma and Immunology. 14(1), 83-90.

Potoğlu Erkara, I, Pehlivan, S. \& Tokur, S. (2007). Concentrations of airborne pollen grains in Eskişehir city (Turkey). Journal of Applied Biological Science, 1(1), 32-42.

Punt, W., Hoen, P.P., Blackmore, S., Nilsson, S. \& Le Thomas, A. (2007). Glossary of pollen and spore terminology. Review of Palaeobotany and Palynology, 143, 1-81.

Rodríguez-Rajo, F.J., Jato V., \& Aira, M.J. (2003). Pollen content in the atmosphere of Lugo (NW Spain) with reference to meteorological factors (1999-2001). Aerobiologia, 19, 213-225.

Serbes, A.B. \& Kaplan, A. (2014). The survey of pollen and spore dispersal in the atmosphere of Düzce city. Karaelmas Science and Engineering Journal, 4(2), 46-58. 
Sin, A.B., Pınar, N.M., Misırlıgil, Z., Çeter, T., Yıldız, A. \& Alan, Ş. (2007). Polen Alerjisi: Türkiye Alerjik Bitkilerine Genel Bir Bakış. Ankara,Turkey: Engin Yayınevi (in Turkish).

Singh, A.B. \& Shahi, S. (2008). Aeroallergens in clinical practice of allergy in India-ARIA Asia Pacific Workshop report. Asian Pacific Journal of Allergy and Immunology., 26, 245256.

Türkmen, Y., Çeter, T. \& Pınar, N.M. (2018). Analysis of airborne pollen of Gümüşhane Province in northeastern Turkey and its relationship with meteorological parameters. Turkish Journal of Botany., 42, 687-700.
Vega-Maray, A.M., Valencia-Barrera, R., Fernandez-Gonzalez, D. \& Frail, R. (2003). Urticaceae pollen concentration in the atmosphere of North Western Spain. Annals of Agricultural and Environmental Medicine., 10, 249-255.

Yavru, A. (2007). Trabzon atmosferindeki polenlerin araştırılması. Yüksek Lisans Tezi. Gazi Üniversitesi Fen Bilimleri Enstitüsü, Ankara, 